\title{
KARAKTERISASI RESERVOAR MELALUI ANALISIS PETROFISIKA BERDASARKAN DATA LOG SUMUR “TRD” FORMASI AIR BENAKAT
}

\author{
Beny Chasandra $^{* 1}$, Ordas Dewanto ${ }^{1}$, Ni Putu Juniari ${ }^{2}$ \\ ${ }^{1)}$ Jurusan Teknik Geofisika, Universitas Lampung \\ Jl. Prof. Dr. SumantriBrojonegoro No.1 BandarLampung 35145 \\ ${ }^{2)}$ PT Pertamina EP ASSET 1 Jambi \\ Jurusan Teknik Geofisika, FT UNILA \\ e-mail: *1benychasandra26@gmail.com
}

\begin{abstract}
ABSTRAK
Daerah penelitian terletak pada Cekungan Sumatera Selatan, tepatnya pada Formasi Air Benakat yang berada di bagian tenggara Provinsi Jambi. Penelitian ini dilakukan untuk mengetahui dimana zona-zona produktif berdasarkan analisis parameter petrofisika (saturasi air, porositas dan vshale), serta bagaimana karakteristiknya Adapun litologi pada sumur TRD adalah batupasir (sandstone) dengan sedikit kandungan foraminifera di dalamnya. Penentuan ini didasarkan pada hasil analisis petrofisika dengan hasil rata-rata porositas zona 7 pada sumur TRD-10 sebesar 12,4\%, Sw 19,4\% dan Vsh 6,2\%; zona 7 sumur TRD-11 porositas 16,2\%, Sw 41,3\%, dan Vsh 22\%; zona 11 pada sumur TRD-14 porositas 33,2\%, Sw 21,2\% dan Vsh 1,2\%; zona 6 sumur TRD-15, porositas 7,02\%, Sw 32,3\% dan Vsh 5,6\%; zona 7 sumur TRD-17, porositas 9,04\%, Sw 25,6\% dan Vsh 4,6\%; dan zona 4 sumur TRD-19, porositas 23,2\% Sw 13,5\% dan Vsh 7,1\%. Karakteristik reservoar pada sumur TRD ini relatif memiliki saturasi yang rendah di bawah $50 \%$, porositas lebih dari $5 \%$ dan kandungan lempung kurang dari $25 \%$, sehingga zona produktif pada sumur TRD berpotensi gas.
\end{abstract}

\begin{abstract}
The research area was located in South Sumatra Basin on Air Benakat Formation at South-East Jambi Province. The research conducted to know productive the interest zone by petrophysics analysis (volume shale water saturation, and porosity) and its characteristics by well-log. The lithology of TRD Well is sandstone with a few foraminifera. The interpretation based on the petrophysical analysis porosity of the 7th zone on TRD-10 is average $12,4 \%$, saturation water $19,4 \%$ and volume shale $6,2 \%$; the 7 th zone on TRD-11 well is average porosity $16,2 \%$, saturation water $41,3 \%$, and volume shale $22 \%$; the 11 th zone on TRD-14 well is average porosity $33,2 \%$, saturation water $21,2 \%$ and volume shale $1,2 \%$; The 6 th zone TRD-15 well, porosity $7,02 \%$, saturation water $32,3 \%$ and volume shale 5,6\%; On the TRD-17 well of the 7th zone is average the porosity $9,04 \%$, saturation water $25,6 \%$ and volume shale $4,6 \%$; and 4 th zone of TRD-19 well, porosity $23,2 \%$ Saturation water $13,5 \%$ and volume shale $7,1 \%$. The characteristics of hydrocarbon reservoir on TRD Wells have low water saturation is less than $50 \%$, porosity more than $5 \%$ and volume shale less than $25 \%$. From the result of petrophysics parameter value used as the indicator of the productive zone and interpreted that sand reservoir on well TRD has potentially for the reservoir zone with gas prospect.
\end{abstract}

Keywords - petrophysics, water saturation, porosity, volume shale, and netpay 


\section{PENDAHULUAN}

Dalam perkembangan industri yang modern ini minyak dan gas merupakan salah satu sektor yang masih saja sangat diminati, mengingat energi yang tidak terbarukan ini keberadaannya mulai sangat sulit untuk ditemukan. Dalam penentuan suatu hidrokarbon dibutuhkan suatu survei, yaitu survei geologi dan survei geofisika. Metode well log merupakan salah satu diantara dari survei geofisika.

Logging memberikan data yang diperlukan untuk mengevaluasi secara kuantitas banyaknya hidrokarbon di lapisan pada situasi dan kondisi sesungguhnya. Kurva $\log$ memberikan informasi yang cukup tentang sifat-sifat batuan dan cairan. Dari sudut pandang pengambil keputusan, logging adalah bagian yang penting dari proses pemboran dan penyelesaian sumur. Mutlak untuk mendapatkan data log yang akurat dan lengkap. Biaya logging diperkirakan hanya sekitar 5\% dari total biaya eksplorasi sebuah sumur, sehingga adalah kurang bijaksana bila tahap yang penting ini tidak dilaksanakan dengan baik.

Analisis petrofisika sangat penting dalam penentuan karakteristik batuan pada suatu reservoar. Mengingat parameter parameter petrofisika diantaranya penentuan porositas, volume shale permeabilitas, saturasi air dan cut off serta net pay.

\section{TINJAUAN PUSTAKA}

'Lokasi penelitian termasuk dalam provinsi jambi, di mana batas Sub-Cekungan Jambi bagian utara dibatasi oleh tinggian Pegunungan Tigapuluh yang bersebelahan dengan Pegunungan Duabelas yang memisahkan dengan Cekungan Sumatra
Tengah. Kemudian di bagian timur diperkirakan melampar sampai ke arah Selat Malaka dan disebelah selatan berbatasan dengan Sub-Cekungan Palembang, kemudian di sebelah barat dibatasi oleh Sub-Cekungan Palembang Tengah.

Cekungan Sumatera Selatan merupakan cekungan busur belakang (back arc basin). Pembentukan Cekungan Sumatera Selatan sangat dikontrol oleh aktivitas tektonik tua mulai dari Mid. Mesozoikum hingga orogenesa PlioPlistosen yang paling akhir. Perkembangan tektonik cekungan Sumatera sangat dipengaruhi oleh pergerakan konvergen antara lempeng Samudera Hindia dengan Lempeng Asia Tenggara. Sejarah tektonik yang memengaruhi pembentukan Cekungan Sumatera Selatan pada periode Mid-Mesozoik sampai Resen dapat dibagi menjadi 4 episode, yaitu Orogenesa MidMesozoik, Tektonik Kapur Akhir-Tersier Awal, Tectonic Quiescence, dan Orogenesa Plio-Pleistosen

Stratigrafi regional Cekungan Sumatera Selatan memperlihatkan kesamaan unit dan waktu dengan Cekungan Sumatera Tengah. Stratigrafi cekungan Sumatera Selatan terdiri dari beberapa formasi yang berumur Tersier dan terendapkan tak selaras di atas batuan dasar (basement rock) PraTersier, di mana lokasi penelitian terletak pada bagian formasi air benakat yang berumur Miosen Tengah.

\section{TEORI DASAR}

\subsection{Wireline Logging}

Log merupakan suatu grafik kedalaman atau waktu dari suatu kumpulan data yang menunjukkan parameter yang 
diukur secara berkesinambungan di dalam sebuah sumur pemboran. Prinsip dasar wireline $\log$ adalah mengukur parameter sifat-sifat fisik dari suatu formasi pada setiap kedalaman secara kontinyu dari sumur pemboran. Adapun sifat-sifat fisik yang diukur adalah potensial listrik batuan atau kelistrikan, tahanan jenis batuan, radioaktivitas, kecepatan rambat gelombang elastis, kerapatan formasi (densitas), dan kemiringan lapisan batuan, serta kekompakan formasi yang kesemuanya tercermin dari lubang bor.

Well logging adalah suatu teknik untuk mendapatkan data bawah permukaan menggunakan alat ukur yang dimasukkan ke dalam lubang bor untuk evaluasi formasi dan identifikasi dari ciri-ciri batuan di bawah permukaan.

\subsection{Jenis - Jenis Logging}

Sebagai alat logging dan metode penafsiran yang berkembang dalam hal keakurasian dan kecanggihan, memang memegang peran penting dalam proses pengambilan keputusan geologi. Sampai pada saat ini, interpretasi log petrofisika adalah salah satu alat yang paling berguna dan penting yang dapat dimanfaatkan oleh seorang ahli geologi minyak bumi.

$$
\text { Macam - macam log yang }
$$

digunakan diantaranya adalah:

\section{Log Spontaneous Potensial (SP)}

2. Log Resistivitas

3. Log Gamma Ray

4. Log Caliper

5. Log Sonic

6. Log Densitas

7. Log Neutron

\section{3 Interpretasi Kualitatif}

Interpretasi secara kualitatif bertujuan untuk identifikasi lapisan batuan cadangan, lapisan hidrokarbon, serta perkirakan jenis hidrokarbon. Untuk suatu interpretasi yang baik, maka harus dilakukan dengan cara menggabungkan beberapa log. Untuk mengidentifikasi litologi, maka dapat dilakukan interpretasi dari log GR atau log SP. Apabila defleksi kurva GRnya ke kiri atau minimum, kemungkinan litologinya menunjukkan batupasir, batugamping atau batubara, sedangkan untuk litologi shale atau organic shale, maka defleksi kurva Grnya ke kanan atau maksimum.

Untuk membedakan gas atau minyak yang terdapat di dalam formasi dapat dilihat pada gabungan log neutrondensitas. Zona gas ditandai dengan harga porositas neutron yang jauh lebih kecil dari harga porositas densitas, sehingga akan ditunjukan oleh separasi kurva log neutron-densitas yang lebih besar. Dalam zona minyak, kurva neutron atau kurva densitas membentuk separasi positif yang lebih sempit daripada zona gas (dalam formasi bersih).

\subsection{Interpretasi Kualitatif}

Interpretasi data wireline $\log$ secara kuantitatif dengan menggunakan rumus perhitungan. Proses pengerjaan analisis petrofisika adalah menghasilkan data-data yang diperlukan untuk proses analisis geologi lebih lanjut. Data-data yang dihasilkan dari analisis petrofisika, yaitu sepertinya penyediaan parameterparameter di bawah ini :

\subsubsection{Volume Shale (Vsh)}

Perhitungan lapisan yang mempunyai sisipan berupa shale maupun serpih menggunakan persamaan volume shaledapat diperoleh dari Log Gamma Ray, Log SP dan Log Neutron : 


$$
\begin{aligned}
I \text { sh } & =\frac{G R l o g-G R \min }{G R \max -G R \min } \\
V s h & =0.08336\left(2^{3.7 x i s h}-1\right)(1)
\end{aligned}
$$

\subsubsection{Porositas}

Porositas suatu medium adalah bagian dari volume batuan yang tidak terisi oleh benda padat. Ada beberapa macam porositas batuan :

1. Porositas Total

Porositas total merupakan perbandingan antara ruang kosong total yang tidak terisi oleh benda padat yang ada diantara elemen-elemen mineral dari batuan dengan volume total batuan.

$$
\emptyset_{T}=\frac{\emptyset D+\emptyset N}{2}
$$

\section{Porositas Efektif}

Merupakan perbandingan volume pori-pori yang saling berhubungan dengan volume total batuan.

$$
\emptyset_{e}=\sqrt{\frac{\emptyset N \operatorname{cor}^{2}+\emptyset D c o r^{2}}{2}}
$$

- Porositas Densitas

$$
\Phi_{D}=\frac{\rho_{m a-\rho_{b}}}{\rho_{m a-\rho_{f}}}
$$

Kemudian nilai pororsitas dikoreksi terhadap pengaruh shale sebagai berikut :

$$
\phi D c=\phi D-(V s h \times \phi D s h)
$$

Dimana,

$$
\phi D s h=\text { porositas densitas shale }(\%)
$$

\section{-Porositas Neutron}

Porositas neutron didapatkan dari pembacaan pada log neutron. Kemudian nilai porositas neutron dikoreksi terhadap pengaruh Shale dengan rumus sebagai berikut:

$$
\emptyset N C=\emptyset N-(V s h \times \emptyset N s h)
$$

$$
\emptyset N s h=\text { porositas neutron shale }(\%)
$$

\section{- Porositas Sonic}

\section{Perhitungan}

porositas menggunakan $\log$ sonic memerlukan tf dan tma.

Dimana fluida yang diselidiki adalah mud filtrat. Sehingga, Porositas dapat dihitung sbb:

$$
\emptyset_{s}=\frac{\Delta \mathrm{t}-\Delta \mathrm{t} m a}{\Delta \mathrm{t} f-\Delta \mathrm{t} m a}
$$

\subsubsection{Penentuan Formation Resistivity Water (Rw)}

\section{- Metode PickettPlot}

Metode pickett plot didasarkan pada Observasi bahwa nilai Rt (true resistivity) adalah fungsi dari nilai porositas $(\Phi)$, saturasi air $(\mathrm{Sw})$ dan factor sementasi (m). Metode ini menggunakan crossplot nilai porositas dan nilai resistivitas dalam (ILD atau LLD ).

\subsubsection{Saturasi Air (Sw)}

Saturasi atau kejenuhan air formasi adalah rasio dari volume pori yang terisi oleh air dengan volume porositas total. Tujuan menentukan saturasi air adalah untuk menentukan zona yang mengandung hidrokarbon, jika air merupakan satu-satunya fluida yang terkandung dalam pori-pori batuan, maka nilai $\mathrm{Sw}=1$, tetapi apabila pori-pori batuan mengandung fluida hidrokarbon maka nilai $\mathrm{Sw}<1$. Archie menyusun persamaannya, yang kemudian kita kenal dengan Archie formula

$$
S w^{n}=\frac{Q}{\phi_{m}} \frac{R_{w}}{R_{t}}
$$

Dari persamaan Archie tersebut, diturunkan menjadi beberapa persamaan

Dimana, 
yang cocok digunakan pada Shalysand formation, antara lain :

Persamaan Simandoux :

$$
S_{w}=\frac{C \cdot R_{W}}{\phi^{2}}\left[\sqrt{\frac{5 \cdot \phi^{2}}{R_{t} R_{W}}+\left(\frac{V_{s h}}{R_{s h}}\right)^{2}-\left(\frac{V_{s h}}{R_{s h}}\right)}\right]
$$

Persamaan Indonesia :

$$
\frac{1}{\sqrt{R_{t}}}=\left(\sqrt{\frac{\phi^{m}}{a \times R_{w}}}+\frac{v_{c l}^{1-0,5 V_{s h}}}{\sqrt{R_{s h}}}\right) \times S_{w}^{\frac{n}{2}}
$$

Dimana :

$$
\begin{array}{ll}
\mathrm{Sw} & =\text { Saturasi air formasi (\%) } \\
\mathrm{F} & =\text { Faktor formasi } \\
\mathrm{Rw} & =\text { Resistivitas air formasi (ohm-m) } \\
\mathrm{Rt} & =\text { Resistivitas sebenarnya, dibaca } \\
& \text { dari kurva lld (ohm-m) } \\
\mathrm{Rsh} & =\text { Resistivitas pada shale (ohm-m) } \\
\mathrm{C} & =\text { Konstanta, (batupasir } 0.4 \text { dan untuk } \\
& \text { batugamping 0.45) }
\end{array}
$$

\subsubsection{Permeabilitas (K)}

Permeabilitas adalah suatu pengukuran yang menyatakan tingkat kemudahan dari fluida untuk mengalir di dalam formasi suatu batuan satuannya adalah darcy. Satu darcy didefinisikan sebagai permeabilitas dari fluida sebesar satu sentimeter kubik per detik dengan kekentalan sebesar satu centipoises mengalir dalam tabung berpenampang sebesar satu sentimeter persegi di bawah gradien tekanan satu atmosfer per sentimeter persegi.

$$
K=\left(a \frac{\phi^{b}}{S w^{c}}\right)
$$

Dimana :

$$
\begin{array}{ll}
\mathrm{K} & =\text { Permeabilitas }(\mathrm{mD}) \\
\mathrm{S}_{\mathrm{w}} & =\text { Saturasi air }(\%) \\
\phi \mathrm{e} & =\text { porositas efektif }(\%) \\
\text { Nilai a,b,c } & =\text { konstanta }(\mathrm{a}=10000, \mathrm{~b}= \\
4.5, \mathrm{c}=2) . &
\end{array}
$$

\section{HASIL DAN PEMBAHASAN}

\subsection{Penentuan Zona Reservoar}

Penentuan zona reservoar dilakukan dengan menggunakan analisis quick look dimana dengan memperhatikan nilai hasil pembacaan alat log gamma ray, log resistivitas, log densitas, dan log neutron. Pada zona reservoar akan menunjukan nilai pembacaan log gamma ray yang rendah, nilai resistivitas yang tinggi, nilai densitas yang rendah, dan nilai neutron yang rendah. Berdasarkan analisis tersebut diperoleh satu zona reservoar pada masing-masing sumur.

Pada sumur TRD-10 zona reservoar berada pada interval kedalaman 1496$1507 \mathrm{~m}$, TRD-11 pada interval 1500$1509 \mathrm{~m}$, TRD-14 pada interval 1431$1442 \mathrm{~m}$, TRD-15 pada interval 1490$1501 \mathrm{~m}$, TRD-17 pada interval 1476$1485 \mathrm{~m}$, dan TRD-19 pada interval 1482$1489 \mathrm{~m}$.

\subsection{Penentuan Kandungan Lempung}

Penentuan kandungan lempung dilakukan pada sumur "TRD" terutama pada bagian zona - zona reservoarnya. Pada sumur TRD-10 kandungan lempung di zona produktif pada zona 7 yang memiliki ketebalan lapisan $11 \mathrm{~m}$ dengan lithologi dominan shalysand memiliki rata-rata Vshale $6.2 \%$. Pada sumur TRD-11 kandungan lempung di zona produktif pada zona 7 yang memiliki ketebalan lapisan $9 \mathrm{~m}$ dengan lithologi dominan shalysand memiliki rata-rata Vshale $22 \%$. Pada sumur TRD-14 kandungan lempung di zona produktif pada zona 11 yang memiliki ketebalan lapisan $11 \mathrm{~m}$ dengan lithologi dominan shalysand memiliki ratarata Vshale $1.2 \%$. Pada sumur TRD-15 kandungan lempung di zona produktif pada zona 6 yang memiliki ketebalan lapisan $11 \mathrm{~m}$ dengan lithologi dominan 
shalysand memiliki rata-rata Vshale $5.6 \%$. Pada sumur TRD-17 kandungan lempung di zona produktif pada zona 7 yang memiliki ketebalan lapisan 9m dengan litologi dominan berupa shalysand memiliki rata-rata Vshale $4.6 \%$. Pada sumur TRD-19 kandungan lempung di zona produktif pada zona 4 yang memiliki ketebalan lapisan $7 \mathrm{~m}$ dengan lithologi dominan shalysand memiliki rata-rata Vshale $7.1 \%$.

\subsection{Penentuan Nilai Resistivitas Air Formasi}

Penentuan nilai resistivitas air formasi (Rw) dilakukan dengan menggunakan metode picket plot dengan crossplot antara nilai porositas dengan nilai log resistivitas (lld). Diperoleh nilai Rw pada sumur TRD10 sebesar 0.119, sumur TRD-11 sebesar 0.106, sumur TRD-14 sebesar 0.138 , sumur TRD-15 sebesar 0.16, sumur TRD-17 sebesar 0.149 dan sumur TRD-19 sebesar 0.175. Dalam penentuan Rw menggunkan picket plot dilakukan pada zona water bearing, kemudian dilakukan crossplot antara porositas dan Rt (LLD) dan ditarik garis yang diasumsikan nilai Sw $100 \%$.

\subsection{Penentuan Nilai Porositas dan Saturasi Air}

Penentuan nilai porositas dan saturasi air dilakukan pada zona produktif sumur TRD. Pada penentuan porositas menggunakan model porositas neutron density. Sedangkan untuk penentuan saturasi air menggunakan model simandoux, dikarenakan pada sumur penelitiain termasuk formasi yang tidak bersih dengan mengandung shale atau lempung.
Pada sumur TRD-10 diperoleh porositas rata-rata sebesar $12.4 \%$ dan harga rata-rata saturasi air sebesar 19.4\%, sehingga diperkirakan jenis hidrokarbon tersebut merupakan dalam bentuk gas.

Pada sumur TRD-11 diperoleh porositas rata-rata sebesar $16.2 \%$ dan harga rata-rata saturasi air sebesar $41.3 \%$, sehingga diperkirakan jenis hidrokarbon tersebut merupakan dalam bentuk gas.

Pada sumur TRD-14 diperoleh porositas rata-rata sebesar $33.2 \%$ dan harga rata-rata saturasi air sebesar $21.3 \%$, sehingga diperkirakan jenis hidrokarbon tersebut merupakan dalam bentuk gas.

Pada sumur TRD-15 diperoleh porositas rata-rata sebesar $7 \%$ dan harga rata-rata saturasi air sebesar $32.3 \%$, sehingga diperkirakan jenis hidrokarbon tersebut merupakan dalam bentuk gas.

Pada sumur TRD-17 diperoleh porositas rata-rata sebesar $9 \%$ dan harga rata-rata saturasi air sebesar $25.6 \%$, sehingga diperkirakan jenis hidrokarbon tersebut merupakan dalam bentuk gas.

Pada sumur TRD-19 diperoleh porositas rata-rata sebesar $21.3 \%$ dan harga rata-rata saturasi air sebesar $13.5 \%$, sehingga diperkirakan jenis hidrokarbon tersebut merupakan dalam bentuk gas.

\subsection{Penentuan Nilai Cut Off}

Penentuan cut off pada setiap sumur TRD dilakukan dengan teknik crossplot. Untuk cut off porositas yaitu dilakukan dengan crossplot antara permeabilitas dengan porositas. Nilai cut off permeabilitas sendiri adalah $1 \mathrm{mD}$ berdasarkan acuan untuk nilai terendah fluida dapat mengalir (sumber: buku Adi Harsono), dan persamaan regresi yang digunakan adalah jenis regresi linear. 
Pada sumur TRD-10 diperoleh nilai cut off porositas sebesar $12.1 \%$, sumur TRD-11 sebesar $6.73 \%$, sumur TRD-14 sebesar $12 \%$, sumur TRD-15 sebesar $12.9 \%$, sumur TRD17 sebesar 13.6\%, dan sumur TRD-19 sebesar $13 \%$, dan jika dirata-ratakan maka diperloeh nilai cut off porositas pada sumur TRD sebesar $11.5 \%$, nilai rata - rata ini kemudian yang nantinya akan digunakan untuk cut off Vshale.

Setelah dilakukan cut off porositas yang didapat sebesar $11.5 \%$, dilanjutkan dengan cut off Vshale, yaitu dengan crossplot porositas dan nilai Vshale. Proses crossplot pada setiap sumur untuk cut off Vshale ini juga dibantu dengan menggunakan model regresi linear sehingga diperoleh nilai cut off Vshale.

Dari proses tersebut maka menghasilkan nilai cut off Vshale untuk sumur TRD-10 sebesar $37.4 \%$, pada sumur TRD-11 sebesar 54.4\%, pada sumur TRD14 sebesar 49\%, pada sumur TRD-17 sebesar 30\%, dan pada sumur TRD-19 sebesar $56.6 \%$.

Nilai rata-rata cut off Vshale sebesar $48.9 \%$ yang didapatkan kemudian digunakan untuk proses lumping dimana nantinya akan dihasilkan netpay dari reservoar yang mengandung hdrokarbon. Adapun untuk nilai cut off saturasi pada penelitian ini menggunakan nilai acuan sebesar 0.65 atau 65\% (sumber : Buku Ajar Petrofisika Log).

\subsection{Penentuan Nilai Net Res dan Net Pay}

Pada penelitian ini untuk zona net reservoar atau net summary didapatkan dengan hanya nilai penggal dari Vshale dan nilai penggal porositas. Sedangkan untuk net pay digunakan nilai penggal Vshale, porositas dan saturasi air, sehingga didapatkan zona bersih hidrokarbonnya. Dimana untuk nilai penggal yang akan digunakan yaitu nilai penggal porositas sebesar $11.5 \%$, nilai penggal kandungan lempung sebesar $48.9 \%$ dan nilai penggal saturasi air $(\mathrm{Sw})$ sebesar $65 \%$.

Pada sumur TRD-10, zona net pay memiliki ketebalan $3.2 \mathrm{~m}$ yang relatif tipis dibandingakan dengan ketebalan net res sebesar $10 \mathrm{~m}$, dan memiliki porositas res sebesar $17.2 \%$, porositas net sebesar $18.5 \%$, Vshale res sebesar 13\%, Vshale net sebesar 15.3\%, dan Sw res sebesar 81.2\%, dan Sw net sebesar $66.8 \%$.

Pada sumur TRD-11, zona net pay memiliki ketebalan $6.5 \mathrm{~m}$, sedangkan net res sebesar $8.3 \mathrm{~m}$, dan memiliki porositas res sebesar $19.9 \%$, porositas net sebesar $21 \%$, Vshale res sebesar $19.1 \%$, Vshale net sebesar $16.3 \%$, dan $\mathrm{Sw}$ res sebesar $57.1 \%$, dan Sw net sebesar 52.7\%.

Pada sumur TRD-14, zona net pay memiliki ketebalan $9.6 \mathrm{~m}$, sedangkan net res sebesar $9.6 \mathrm{~m}$, dan memiliki porositas res sebesar $19.7 \%$, porositas net sebesar $19.7 \%$, Vshale res sebesar $31.7 \%$, Vshale net sebesar $31.7 \%$, dan $\mathrm{Sw}$ res sebesar $27.6 \%$, dan Sw net sebesar $27.6 \%$.

Pada sumur TRD-15, zona net pay memiliki ketebalan $4.5 \mathrm{~m}$, sedangkan net res sebesar $4.5 \mathrm{~m}$, dan memiliki porositas res sebesar $20.1 \%$, porositas net sebesar $20.1 \%$, Vshale res sebesar $20.2 \%$, Vshale net sebesar $20.2 \%$, dan $\mathrm{Sw}$ res sebesar 66.2\%, dan Sw net sebesar 66.2\%.

Pada sumur TRD-17, zona net pay memiliki ketebalan $7.5 \mathrm{~m}$, sedangkan $n e t$ res sebesar $7.5 \mathrm{~m}$, dan memiliki porositas res sebesar $32.7 \%$, porositas net sebesar $32.7 \%$, Vshale res sebesar $14.8 \%$, Vshale net sebesar $14.8 \%$, dan $\mathrm{Sw}$ res sebesar $25.6 \%$, dan Sw net sebesar 25.6\%.

Pada sumur TRD-19, zona net pay memiliki ketebalan $6.9 \mathrm{~m}$, sedangkan net res sebesar $7.1 \mathrm{~m}$, dan memiliki porositas res sebesar $25.8 \%$, porositas net sebesar $25.9 \%$, Vshale res sebesar $8.6 \%$, Vshale 
net sebesar $8.1 \%$, dan $\mathrm{Sw}$ res sebesar $50.7 \%$, dan Sw net sebesar 50.1\%.

\section{KESIMPULAN}

\subsection{Kesimpulan}

Dari hasil dan pembahasan yang telah dilakukan dalam penelitian ini, dapat disimpulkan bahwa;

1. Berdasarkan analisis kualitatif diketahui tipe litologi zona reservoar merupakan batupasir (sandstone) dengan sedikit kandungan foraminifera.

2. Nilai penggal (cut off) didapat dengan crossplot yaitu untuk porositas sebesar $11.5 \%$ dan Vshale sebsar $48.9 \%$, sedangkan untuk saturasi berdasarkan acuan buku sebesar $65 \%$ dan permeabilitas sebesar $1 \mathrm{mD}$.

3. Berdasarkan hasil analisis, zona produktif pada sumur TRD-10 terdapat pada zona 7 , sumur TRD-11 pada zona 7, sumur TRD-14 pada zona 11 , sumur TRD-15 pada zona 6 ,sumur TRD-17 pada zona 7 ,dan sumur TRD-19 pada zona 4.

4. Pada zona produktif sumur TRD-10 memiliki karakteristik reservoar dengan porositas $12.4 \%$, Sw $19.4 \%$ dan Vsh $6.2 \%$, pada sumur TRD-11 porositas $16.2 \%$, Sw $41.3 \%$ dan Vsh $22 \%$, pada sumur TRD-14 porositas $33.2 \%$, Sw $21.3 \%$ dan Vsh $1.2 \%$, pada sumur TRD-15 porositas 7\%, Sw $32.3 \%$ dan Vsh $5.6 \%$, pada sumur TRD-17 porositas 9\%, Sw $25.6 \%$ dan Vsh $4.6 \%$ sedangkan pada sumur TRD19 porositas $21.3 \%$, Sw $13.5 \%$ dan Vsh $7.1 \%$.

5. Berdasarkan proses lumping, zona terproduktif terdapat pada sumur TRD-
14 dengan porositas net pay $19.7 \%, \mathrm{Sw}$ net pay $27.6 \%$, Vshale net pay $31.7 \%$, ketebalan net pay $9.6 \mathrm{~m}$

\section{DAFTAR PUSTAKA}

Asquith, G.B. 1982. Basic Well Log Analysis for Geologists. Tulsa, Oklahoma: AAPG. Methods in Exploration Series.

Asquith, G.B. dan Krygowski D.A. 2004. Basic Well Log Analysis, 2nd Edition. Tulsa, Oklahoma: AAPG. AAPG Methods in Exploration Series 16.

Dewanto, O. 2009, Buku Ajar Well Logging, Lampung: Universitas Lampung.

Dewanto, O. 2016, Petrofisika Log, Edisi 1 November 2016. Lampung: Universitas Lampung.

Harsono, A. 1997. Evaluasi Formasi dan Aplikasi Log, Edisi Revisi-8 Mei 1997. Jakarta: Schlumberger Oilfield Service.

Koesoemadinata, R.P., 1980, Geologi Minyak dan Gasbumi, Edisi Kedua, Bandung: Institut Teknologi Bandung. Labo, J. 1987. A Practical Introduction to Borehole Geophisics. Tulsa : Society of Exploration Geophisicist.

Pertamina, 2015, Exploitation Sub Surface Funneling, Jakarta : PT.Pertamina EP Asset 1.

Rider, M. 2002. The Geological Interpretation of Well Logs, $2^{\text {nd }}$ Edition, revised 2002. Scotland : Whittles Publishing.

Russel, W., 1951, Principles of petroleum Geology, USA:McGraw-Hill book Company Inc.

Schlumberger. 1972. Log Interpretation IPrinciples. Houston: Schlumberger Ltd.

Schlumberger. 1989. Log Interpretation Principles/Applications. Texas: Schlumberger Wireline \& Testing.

Schlumberger. 2007. Interactive Petrophsics User Manual (IP version 
3.4). Scotland: PGL-Senergy

(Program Komputer) 


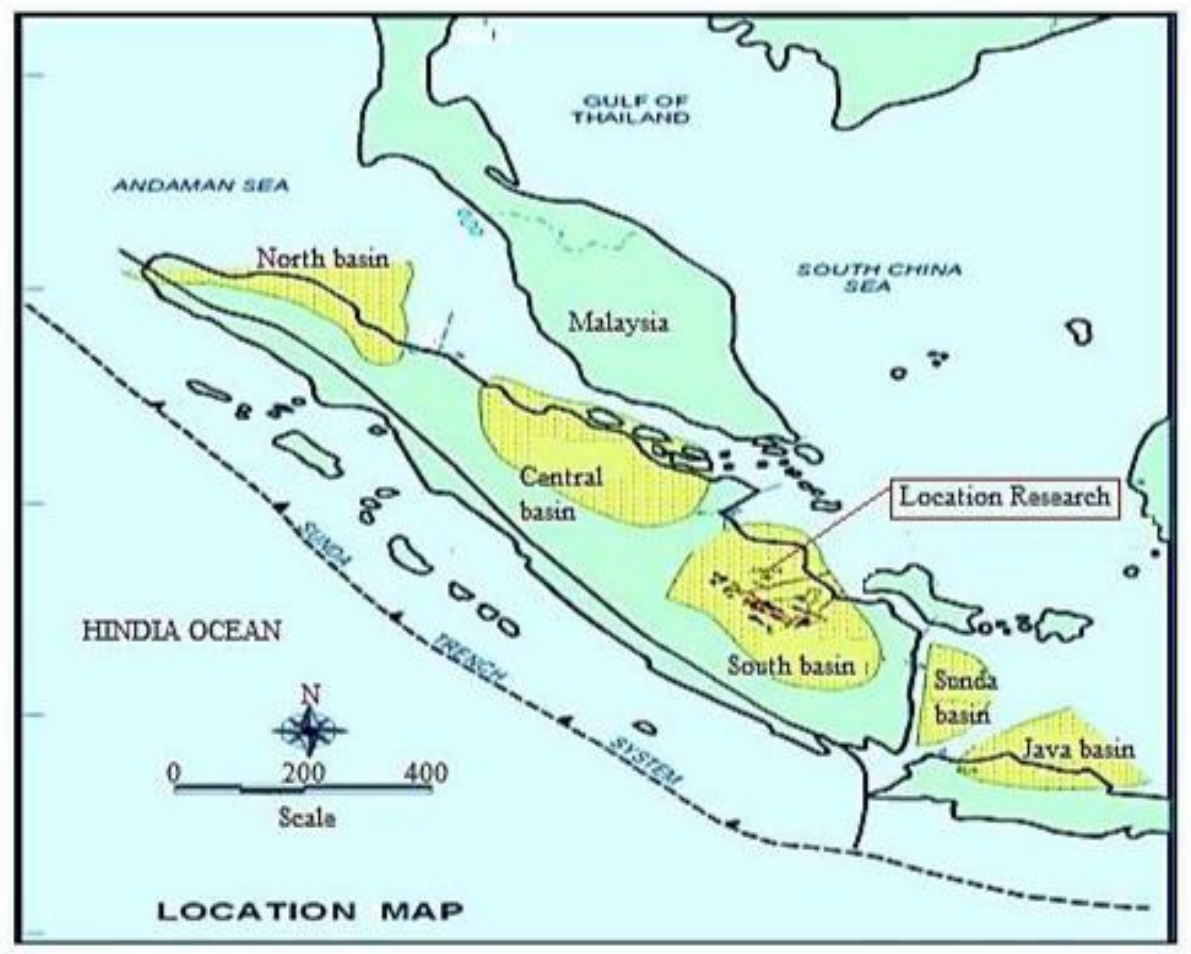

Gambar 1. Peta lokasi penelitian (Koesoemadnata, 1980)

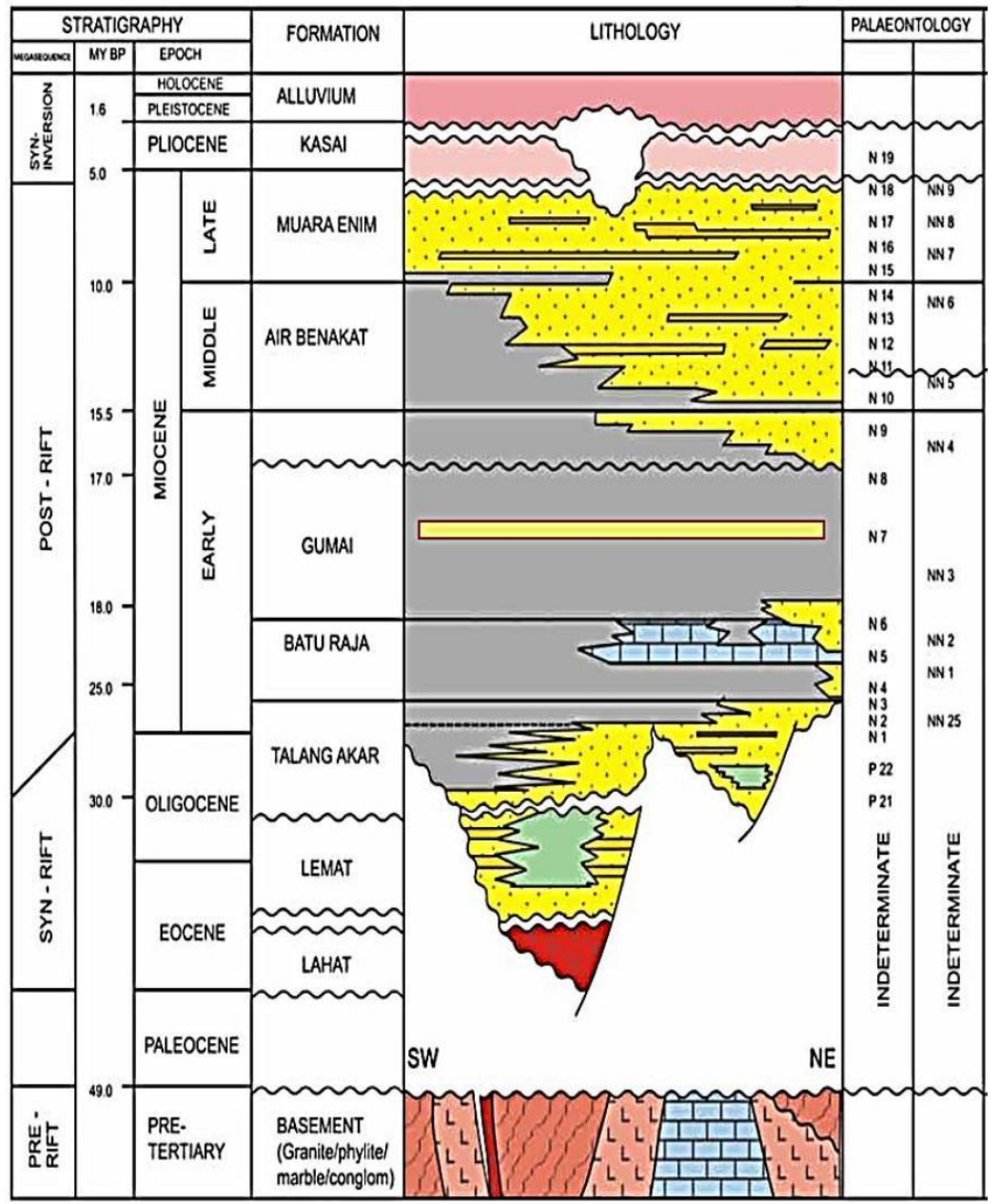

Gambar 2. Stratigrafi daerah penelitian (Pertamina, 2015) 


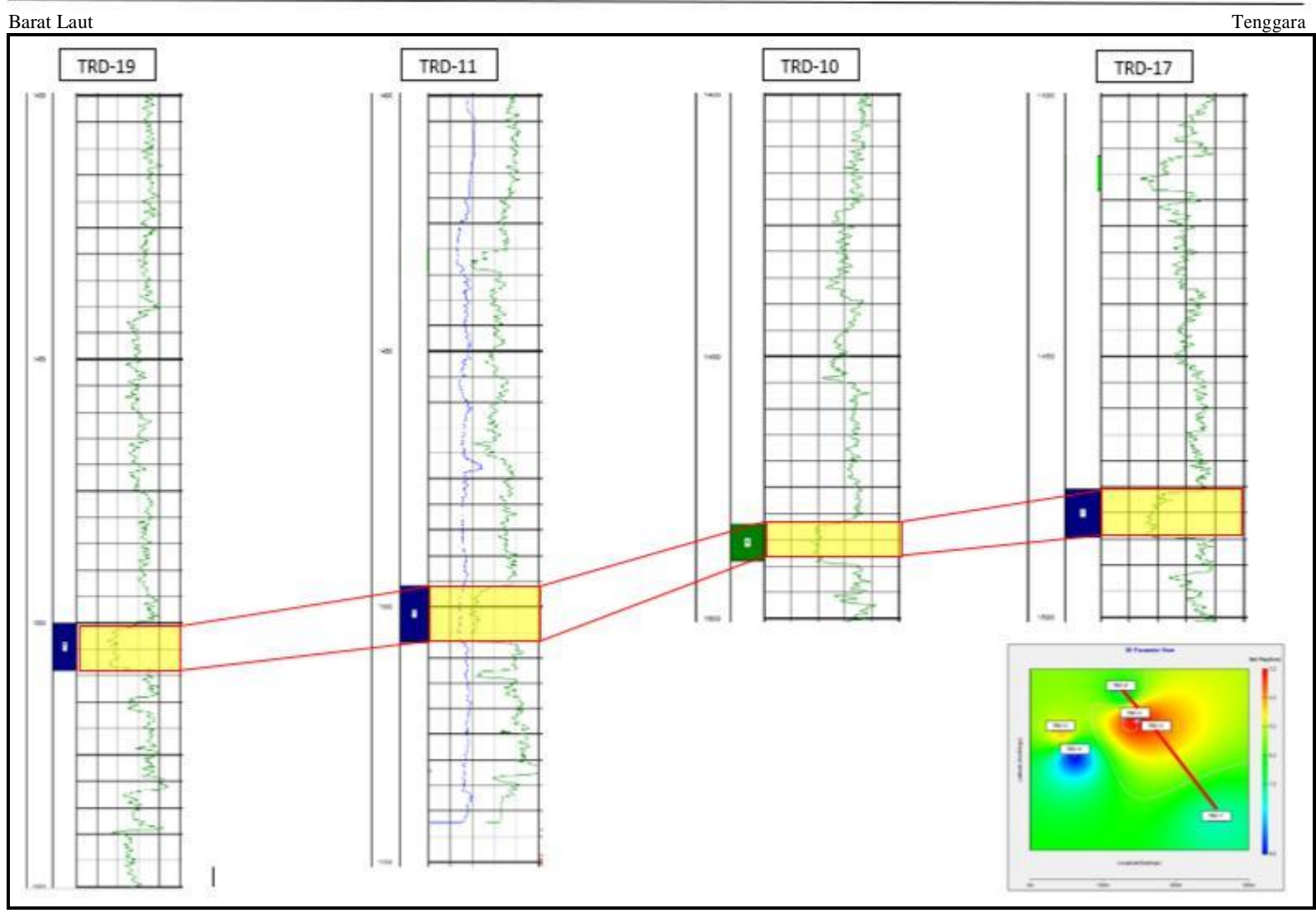

Gambar 3. Korelasi zona reservoar X pada lapangan Y

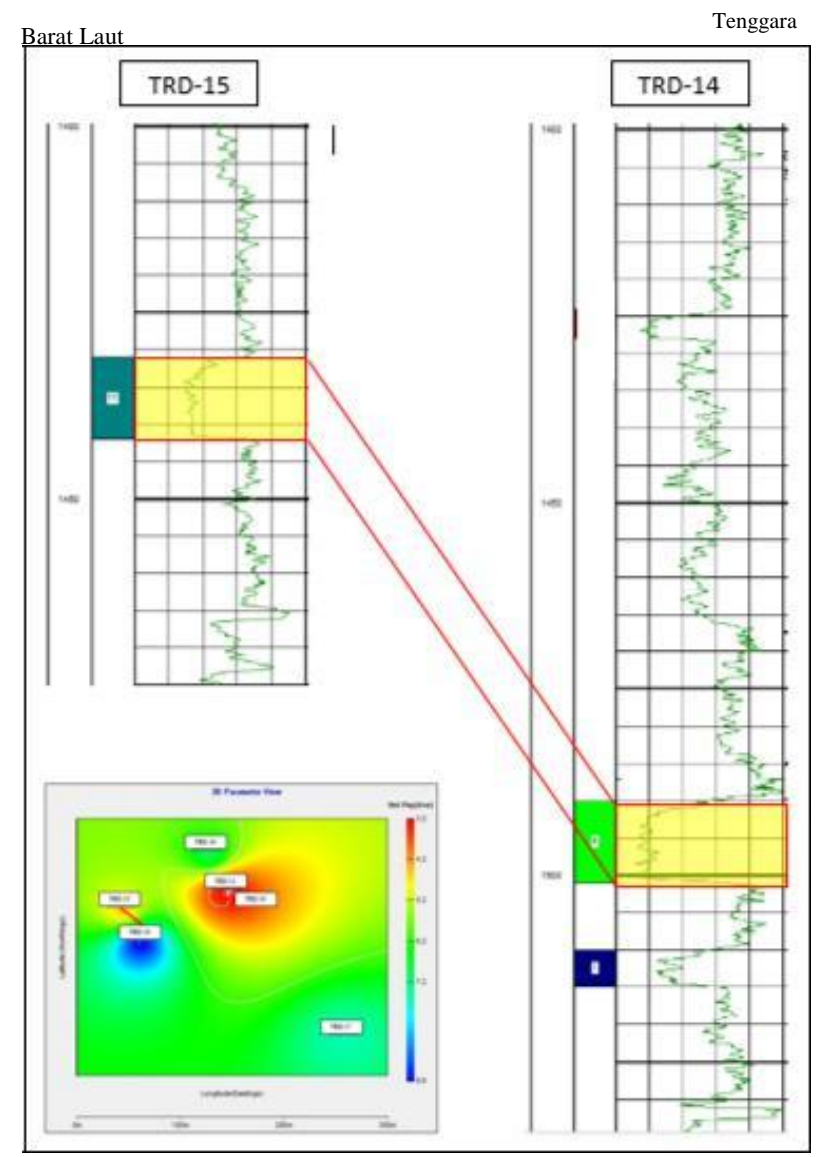

Gambar 3. Korelasi zona reservoar pada sumur TRD-15 dan TRD-14 


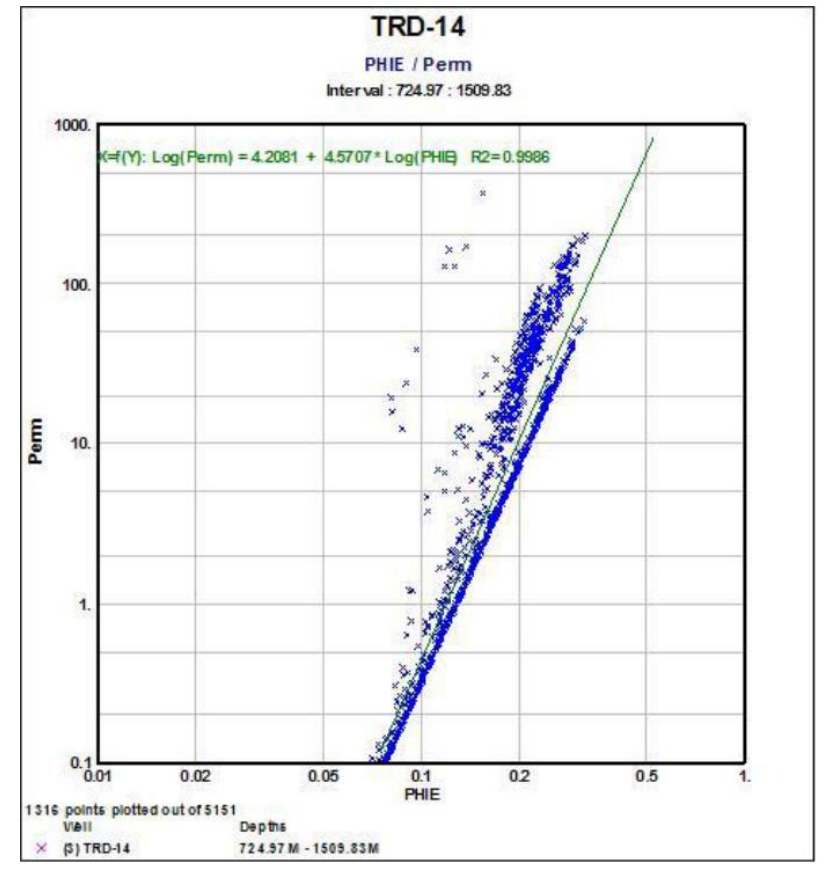

Gambar 3. Cut off porositas sumur TRD-14

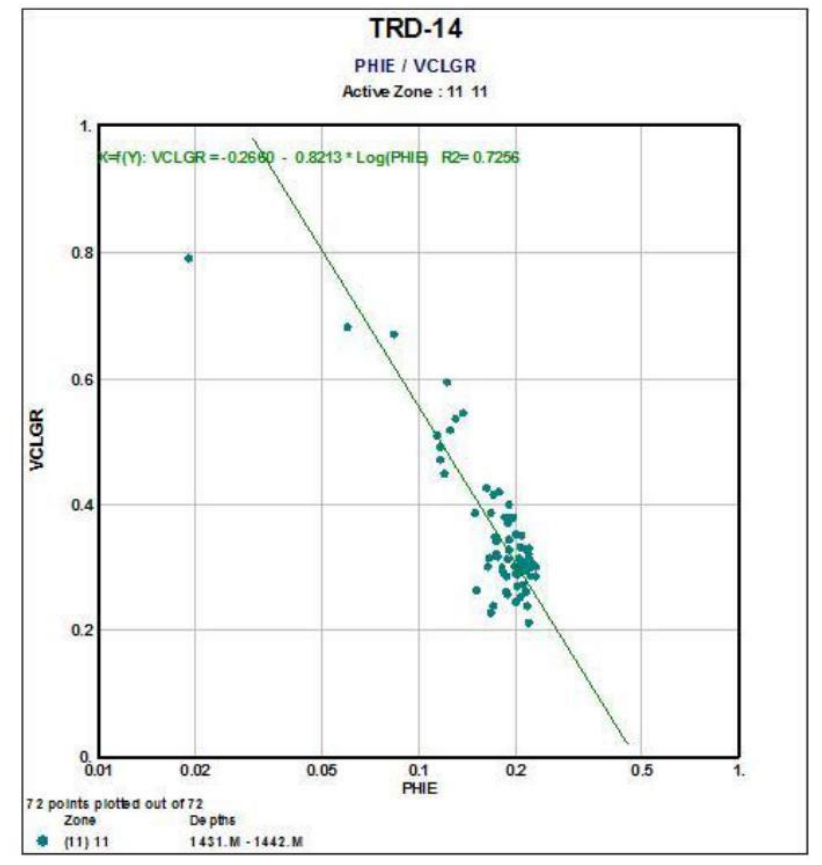

Gambar 4. Cut off Vshale sumur TRD-14

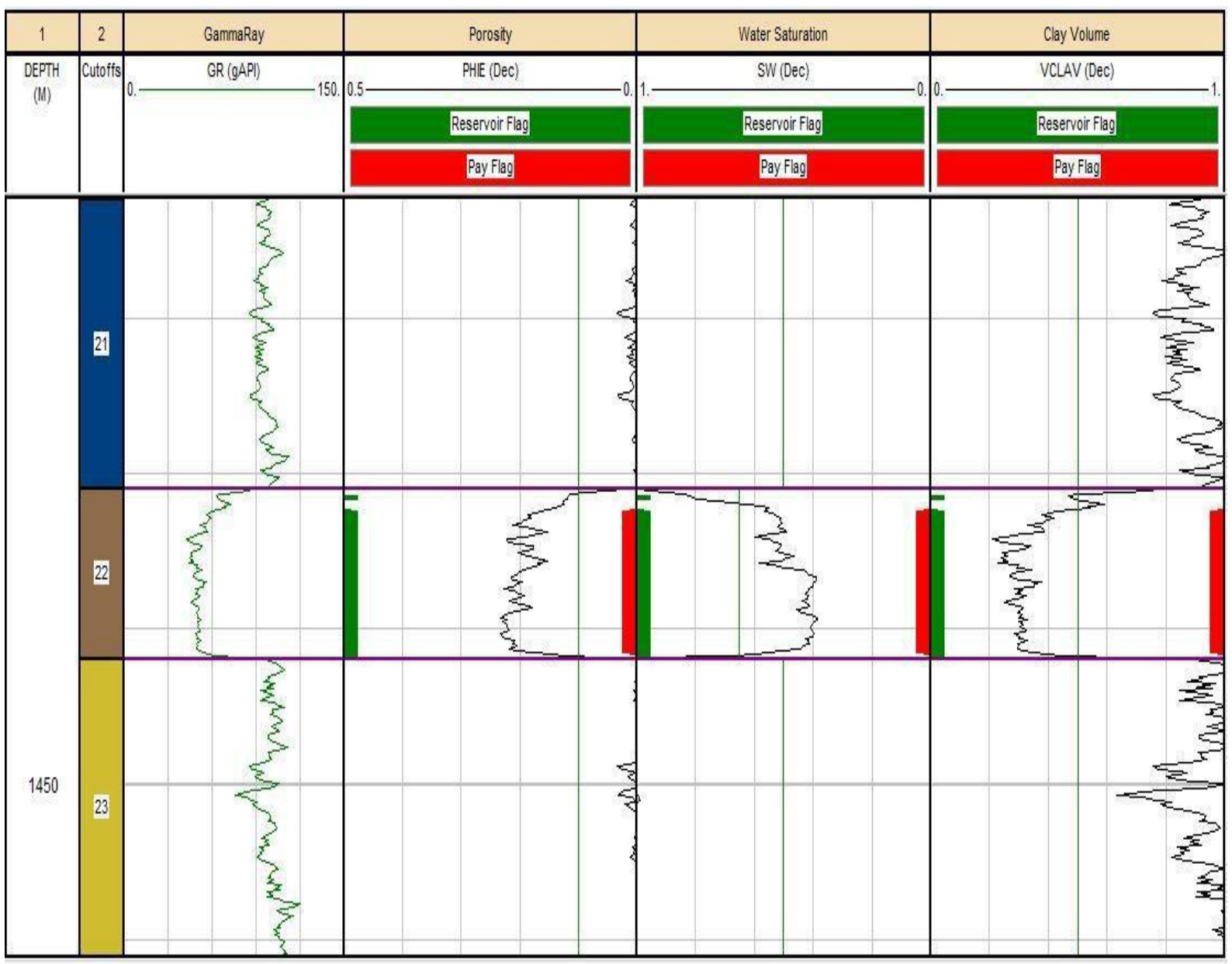

Gambar 5. Net pay pada sumur TRD-14 


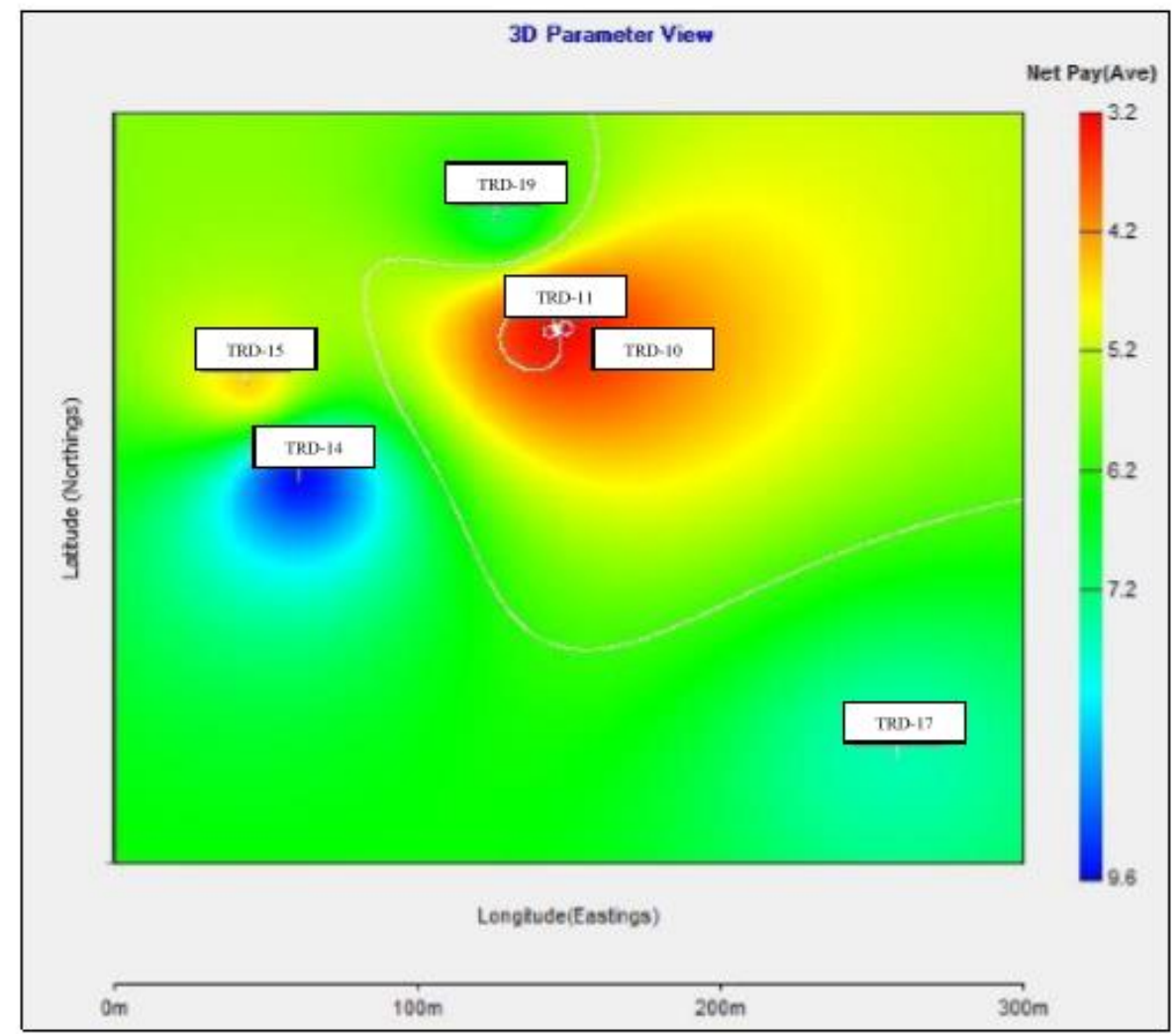

Gambar 6. Peta net pay reservoar $\mathrm{X}$ dalam 2D

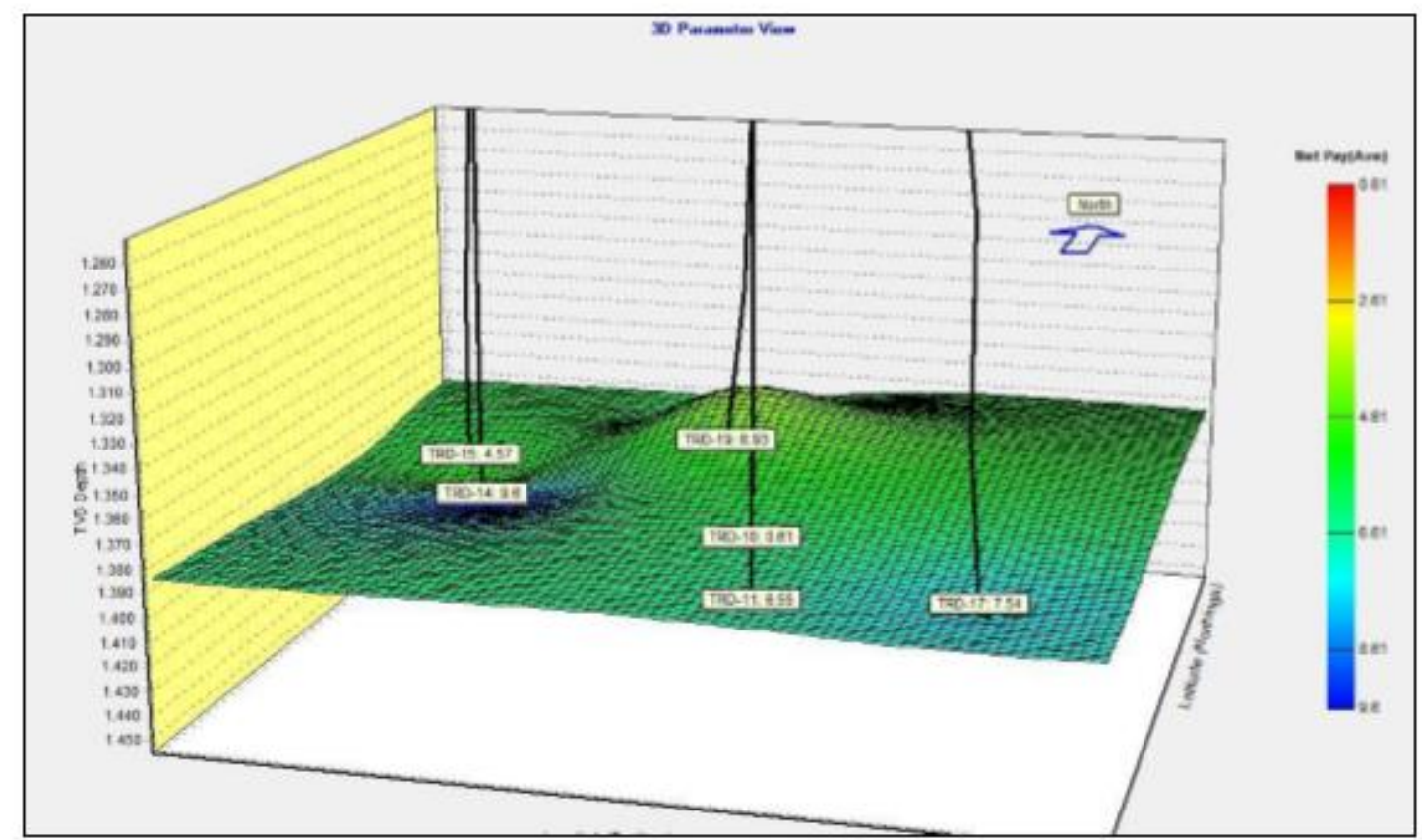

Gambar 7. Peta Net pay reservoar X dalam 3D 